\title{
Same-Gender Marriage: Implications for Social Work Practitioners
}

\author{
Jennifer Fasbinder \\ Emily Monson \\ Darrel Montero \\ Jaime Sanders \\ Annie C. Williams
}

\begin{abstract}
Notably, in 2013, Maryland, Rhode Island, Delaware, and Minnesota became the 10th, 11th, 12th, and 13th states, respectively, to legalize same-gender marriage. Without legal recognition or social support from the larger society, the majority of samegender partnerships in the U.S. are denied privileges and rights that are considered basic for heterosexual marriages. This manuscript draws from a national cross section of published survey data from 1996 to 2013 reporting Americans' attitudes regarding samegender marriage and civil unions. Social work practitioners have broad opportunity to apply their skills to the critical needs facing same-gender partners. After an overview of the legal status of same-gender marriages and their accompanying social and policy issues, recommendations are provided that include identification of specific needs for premarital counseling of same-gender partners and ensuring sensitivity to the myriad challenges they face.
\end{abstract}

Keywords: Same-gender marriage, same-sex marriage, civil union, marriage equality

Same-gender partnerships in the U.S. have had a very tumultuous history. Notably, the 2010 census reported the existence of same-gender couples in $99 \%$ of the counties in this country (Williams Institute, 2011); however, currently only 13 states recognize samegender marriage. Existing without legal and social recognition and support for their family unit is a constant, harsh, and exhausting strain on many same-gender partnerships in this country. These couples are often denied certain privileges and rights that are considered basic for heterosexual marriages. Indeed, some 1,100 legal privileges have been identified as stemming from the institution of legal marriage (Duncan \& Kemmelmeier, 2012). There are also often negative consequences for the mental and emotional well-being of the individuals within these family units, which, many times, include children. This is sometimes referred to as minority stress theory (Alessi, 2013; Ponterotto, Casas, Suzuki, \& Alexander, 2010). The 2010 Census Bureau reported that 115,000 same-gender couples out of 594,000 have at least one child (Lofquist, 2011). Some studies have revealed that partners in same-gender relationships desire the recognition of marriage for their relationship regardless of whether or not such recognition is accompanied by additional benefits (Shulman, Gotta, \& Green, 2012).

Social work practitioners have broad opportunity to apply their practice to the many areas of need facing same-gender partners, using their training as practitioners, advocates, and researchers to intervene effectively at multiple levels (Rostosky \& Riggle, 2011).

Jennifer Fasbinder, Emily Monson, Jaime Sanders, and Annie C. Williams are MSW students in the School of Social Work at Arizona State University. Darrel Montero, Ph.D., is an Associate Professor in the School of Social Work at Arizona

State University in Phoenix. The authors wish to thank the following organizations for their generosity in allowing the use of their survey data: Gallup Organization (2013), CBS News/New York Times Poll (2012), and CNN/ORC Poll (2013)

Copyright (C) 2013 Advances in Social Work Vol. 14 No. 2 (Fall 2013), 416-432 
This article highlights potential avenues for these professionals to assist with the issues faced by same-gender marriages, after an overview of the relatively recent evolution of the legal status of same-gender marriages, and their accompanying social and policy issues. In addition, we report national poll data from 1996 to 2013 which address America's attitudes regarding same-gender marriage and civil unions. Our rationale for presenting these national survey data is that there is ample evidence that public opinion impacts policy formation, such as the legalization of same-gender marriage in this case (Agnone, 2007; Blekesaune \& Quadagno, 2003; Zernike, 2013).

\section{Legal Background}

In the U.S., the legal status of same-gender partnerships began to emerge sporadically as a social issue throughout the 1960s and 1970s, predominantly through the voices of journalists, playwrights, and other writers and artists. A seminal legal challenge to Minnesota's denial of a marriage license to a gay activist in the early 1970s was unsuccessful (Baker v. Nelson, 1972), followed by similar decisions in Kentucky and Washington State (Geidner, 2011). Later in that decade, the U.S. Episcopal Church considered banning the ordination of openly gay priests (Sheppard, 1979). It was not until 1989 that the issue began to take shape and gain momentum, and was swept up in the rising wave of the gay and lesbian rights movement of the 1980s. In that year, in two reversals of traditional U.S. thinking on marriage and family, New York's judiciary ruled that for the purposes of rent-control laws, two gay men qualified as a family, and the State Bar of California publicly advocated recognition of same-gender marriages (Gutis, 1989).

DOMA. Though the stage was readying for a pendulum swing, the aforementioned steps were not widely accepted or integrated into America's social or political fabric just yet. In 1996, both houses of the U.S. Congress passed the Defense of Marriage Act (DOMA) by large majorities, restricting to opposite-sex marriages all federal marriage benefits, including insurance benefits (for government employees), Social Security survivors' benefits, immigration, and tax filing status (Epstein, 2012; Franck, 2011; Willetts, 2011). DOMA's provisions restricting same-gender couples from rights and benefits with regard to bankruptcy, public employee benefits, estate taxes, and immigration were subsequently held to be unconstitutional in eight federal courts. DOMA also required recognition of inter-state marriage status only for opposite-sex marriages; the states were left with the ability to determine whether to allow same-gender marriages or unions within their borders, and whether they would recognize marriages performed legally in other states (Zupcofska, 2010).

In 2000, Vermont became the first state to legally recognize same-sex unions, referred to as civil unions, granting same-gender couples certain rights and benefits of marriage ("Vermont Lawyer," 2013). It took years for additional states to begin to react, some expanding on their definitions of legally recognized same-gender partnerships, and some solidly rejecting any such expansion. Domestic partnership policies were implemented in seven states, namely, California, Maine, New Jersey, Washington, Oregon, Nevada, and Wisconsin (Willetts, 2011). In 2008, New Hampshire passed

legislation allowing for civil unions. However, that same year, Arizona, Florida, and 
California amended their state constitutions to legally define marriage in a way that outlawed same-gender unions (Whitehead, 2010).

California's mechanism for outlawing same-gender marriage was ballot Proposition 8 (Sherkat, Powell-Williams, Maddox, \& Mattias de Vries, 2011), which actually reversed an earlier state Supreme Court decision holding that same-gender couples have a constitutional right to marry. Existing same-gender marriages were "grandfathered" in and allowed to stand, under a subsequent California Supreme Court decision upholding Proposition 8. In Perry v. Schwarzenegger (2010), Proposition 8 was overturned as a violation of the Due Process and Equal Protection clauses of the U.S. Constitution (Nicolas, 2011). Overall, 41 states have passed state-level versions of DOMA, expressly prohibiting rights for same-gender couples (Ellison, Acevedo, \& Ramos-Wada, 2011; Woodford, Chonody, Scherrer, Silverschanz, \& Kulick, 2012).

Historically, in June 2013, the U.S. Supreme Court struck down DOMA, allowing for federal recognition of same-sex marriage in the states where it was legal. This action provided access for same-gender couples to over 1,100 federal benefits which were formerly denied to them. The Court also declined to consider a case challenging Proposition 8. As such, on June 28, 2013, gay and lesbian couples resumed marriage ceremonies in California (Leitsinger, 2013).

\section{Religion and Spirituality}

Walls (2010) observes that failure to recognize and address the importance of religious motivations about same-gender marriage could result in a substantial portion of the U.S. population remaining opposed to equal rights for same-gender couples. As pointed out by Judge Walker (in Perry v. Schwarzenegger), moral views are the primary basis of objection that individuals have against same-gender couples (Franck, 2011).

There are clearly vast differences of opinion among churches on this topic. Many liberal religious groups and movements have promoted rights and recognition for samegender couples (Sherkat et al., 2011). However, opposition to same-gender marriage remains high among conservative Protestant and sectarian faith communities (Ellison et al., 2011), and Sherkat and colleagues found that both denominational ties and religious participation traditionally have negative influences on support for same-gender marriage. Incidentally, it has been suggested that Canada's great strides toward equal rights for lesbian and gay citizens are due to the fact that Canada does not have a strong religious right advocating against their equal rights (Green, Murphy, \& Blumer, 2010).

The Vatican publicly opposes same-gender marriage and same-gender relationships in general. However, in 2013, Pope Francis declared that homosexuals should not be marginalized stating, "Who am I to judge?" In addition, when he was asked if he approved of homosexuality, the Pope replied, "Tell me: When God looks at a gay person, does he endorse the existence of this person with love, or reject and condemn this person? We must always consider the person" (Goodstein, 2013, p. A1). In concert with this position, Catholic Charities in Massachusetts has declined to place any adoptive children with same-gender couples (Franck, 2011). Similarly, research suggests that U.S. Latinos, 
who are largely Catholic, tend to oppose progressive policy regarding same-gender marriage (Ellison et al., 2011).

Other non-Christian religious groups' attitudes toward same-gender marriage range from outright condemnation by a substantial number of Orthodox Jews and Muslims (Marcus, 2013; Pew Research Religion \& Public Life Project, 2012) to tacit support for those who embrace Reform and Reconstructionist Judaism (Kipnes, 2013). The Conservative Jewish movement approved a ceremony in 2012 to allow same-gender couples to marry. There is no official Buddhist or Hindu position on same-gender marriage (Pew Research Religion \& Public Life Project, 2012).

\section{Family and Adoption Issues}

Gay and lesbian persons often face tensions and dilemmas in the context of family relationships (Green, Murphy, Blumer, \& Palmanteer, 2009). This discord is easily compounded when it progresses from a matter of their own sexuality to the context of a relationship with a member of the same sex. Same-gender couple relationships are often ignored or rejected by parents and relatives, rather than validated, supported, and celebrated (Rostosky \& Riggle, 2011). When they announce to family and friends a decision to get married, they tend to receive mixed reactions (Baker \& Elizabeth, 2012). Same-gender couples that have had wedding ceremonies have reported being told by family members that they will not live "happily ever after," and that their choice of a same-gender partner is "wrong” (Rostosky \& Riggle, 2011, p. 959).

With regard to parenting rights of same-gender couples, many U.S. states protect gay and lesbian parenting without officially recognizing gay and lesbian couples. For instance, almost half of U.S. states recognize second-parent adoption, whereby a child may be adopted by a second parent in the home who is not married to the legal parent of the child (Epstein, 2012).

\section{Healthcare}

While some studies have found that legal and social recognition of same-gender marriage has had positive health outcomes for the LGBT (lesbian, gay, bisexual, and transgender) community (Buffie, 2011), generally, compromised healthcare delivery to this community compared to that provided to the general population is well documented (Bonvicini \& Perlin, 2003; Penniman et al., 2007). One aspect to consider is that a partnered LGBT person is less likely to receive employee-sponsored dependent health insurance coverage (Buffie, 2011). Partnered gay men are much less likely than are married heterosexual men to have access to employer-sponsored dependent coverage, while partnered lesbians have even less opportunity for coverage than married heterosexual women. Moreover, enrolling a same-gender partner or spouse as a dependent frequently requires that an employee "come out" as lesbian or gay if the employee has not done so already (Ponce, Cochran, Pizer, \& Mays, 2010). 


\section{Methods}

The findings of this study are based on previously published opinion polls from the Gallup Organization (2013), CBS News/New York Times Poll (2012), and CNN/ORC Poll (2013). For the Gallup Organization, the design of the sample for personal (face-toface) surveys is that of a replicated area probability sample down to the block level, in the case of urban areas, and down to segments of townships, in the case of rural areas. After stratifying the nation geographically and by size of community according to information derived from the most recent census, over 350 different sampling locations are selected on a mathematically random basis from within cities, towns, and counties that have, in turn, been selected on a mathematically random basis.

The procedures just described are designed to produce samples that approximate the adult civilian population (aged 18 and older) living in private households (that is, excluding those in prisons, hospitals, hotels, and religious and educational institutions, and those living on reservations or military bases) and, in the case of telephone surveys, households with access to either a landline or cell phone. The manner in which the sample is drawn also produces a sample that approximates the distribution of private households in the United States; therefore, survey results can also be projected onto the number of households. For further detailed methodology, see Gallup Organization (2013), CBS News/New York Times Poll (2012), and CNN/ORC Poll (2013).

\section{Results}

Given that same-gender marriage is one of the most controversial and divisive social issues faced by Americans, national polls have been conducted on this topic for nearly two decades. For example, from 1996 to 2012, the Gallup Organization (2013) asked a cross section of Americans the following question: "Do you think marriages between same-sex couples should or should not be recognized by the law as valid, with the same rights as traditional marriages?” (see Table 1). Results showed a notable increase for support for same-gender marriage: In 1996, only 1 in 4 Americans were in support, whereas by November 2012, a majority (53\%) of Americans expressed their support.

In order to tap into Americans' attitudes toward same-gender marriage in a slightly different format, from 2004-2012, the CBS News/New York Times Poll (2012) asked a cross section of Americans: "Which comes closest to your view? Gay couples should be allowed to legally marry. OR, Gay couples should be allowed to form civil unions but not legally marry. OR, There should be no legal recognition of a gay couple's relationship?” (see Table 2). The most striking difference compared to the results reported in Table 1 is that when respondents were provided with three response alternatives, support for legal marriage declines from a majority (53\%) to only $40 \%$ of Americans in support of legal marriage. Approximately one quarter of Americans support civil unions as opposed to legal marriage, while nearly one third of Americans desire no legal recognition of a gay couple's relationship. 
Table 1. Attitudes toward the Legal Recognition of Same-Gender Marriage, 1996-2012

\begin{tabular}{lccc}
\hline & $\begin{array}{c}\text { Should be valid } \\
(\%)\end{array}$ & $\begin{array}{c}\text { Should not be } \\
\text { valid (\%) }\end{array}$ & $\begin{array}{c}\text { No opinion } \\
(\%)\end{array}$ \\
\hline 2012 & 53 & 46 & 2 \\
2012 & 50 & 48 & 2 \\
2011 & 48 & 48 & 4 \\
2011 & 53 & 45 & 3 \\
2010 & 44 & 53 & 3 \\
2009 & 40 & 57 & 3 \\
$2008^{\wedge}$ & 40 & 56 & 4 \\
2007 & 46 & 53 & 2 \\
$2006 \wedge$ & 42 & 56 & 4 \\
$2006^{* \wedge}$ & 39 & 58 & 4 \\
$2005^{*}$ & 37 & 59 & 3 \\
$2004^{*}$ & 42 & 55 & 5 \\
$1999^{*}$ & 35 & 62 & 3 \\
$1996^{*}$ & 27 & 68 & 3 \\
\hline
\end{tabular}

Question: Do you think marriages between same-sex couples should or should not be recognized by the law as valid, with the same rights as traditional marriages?

Note*: [Question was slightly different]: Do you think marriages between homosexuals should or should not be recognized by the law as valid, with the same rights as traditional marriages?

Note^: Asked of a half sample.

Note ${ }^{\mathrm{a}}$ : Data reported two or more times in one year indicate that the same question was asked multiple times.

Note $^{\mathrm{b}}$ : Figures may not total $100 \%$ because of rounding.

Note $^{\mathrm{c}}$ : Random sample of 2,027 adults, aged 18+, living in all 50 U.S. states and the District of Columbia. For results based on these samples of national adults, one can say with $95 \%$ confidence that the margin of error is \pm 3 percentage points ( $T$. Sugar [Gallup Organization], personal communication, September 5, 2013).

Note $^{\mathrm{d}}$ : For each table, the authors have reported all data that were collected by the Gallup Organization. However, it is important to note that the Gallup Organization did not conduct the same survey every year, which explains the occasional gaps in data reported from year to year.

Source: Poll data compiled by the Gallup Organization (2013). 
Table 2. Attitudes toward Same-Gender Marriage and Civil Unions, 2004-2012

\begin{tabular}{ccccc}
\hline & $\begin{array}{c}\text { Legal } \\
\text { marriage } \\
(\%)\end{array}$ & $\begin{array}{c}\text { Civil } \\
\text { unions } \\
(\%)\end{array}$ & $\begin{array}{c}\text { No legal } \\
\text { recognition } \\
(\%)\end{array}$ & $\begin{array}{c}\text { Unsure } \\
(\%)\end{array}$ \\
\hline 2012 & 40 & 23 & 31 & 6 \\
2011 & 38 & 27 & 28 & 7 \\
2010 & 40 & 30 & 25 & 5 \\
2010 & 39 & 24 & 30 & 7 \\
2009 & 33 & 30 & 32 & 5 \\
2009 & 42 & 25 & 28 & 5 \\
2009 & 33 & 27 & 35 & 5 \\
2008 & 30 & 28 & 36 & 6 \\
2007 & 28 & 32 & 35 & 5 \\
2006 & 28 & 29 & 38 & 5 \\
2006 & 27 & 30 & 40 & 2 \\
2005 & 23 & 34 & 44 & 3 \\
2004 & 21 & 32 & 38 & 3 \\
2004 & 28 & 31 & 40 & 3 \\
2004 & 28 & 29 & 40 & 5 \\
2004 & 22 & 33 & & 5 \\
\hline
\end{tabular}

Question: "Which comes closest to your view? Gay couples should be allowed to legally marry. OR, Gay couples should be allowed to form civil unions but not legally marry. OR, There should be no legal recognition of a gay couple's relationship."

Note ${ }^{\mathrm{a}}$ : Data reported two or more times in one year indicate that the same question was asked multiple times.

Note $^{\mathrm{b}}: N=1,197$ adults nationwide with a margin of error of \pm 3 percentage points.

Note ${ }^{\mathrm{c}}$ : For each table, the authors have reported all data that were collected by the CBS News/New York Times Poll. However, it is important to note that the CBS News/New York Times Poll did not conduct the same survey every year, which explains the occasional gaps in data reported from year to year.

Source: Poll data compiled by the CBS News/New York Times Poll (2012).

To gain yet another perspective, Table 3 presents CNN/ORC Poll (2013) data from 2008 to 2013 derived from a slightly different question: "Do you think marriages between gay and lesbian couples should or should not be recognized by the law as valid, with the same rights as traditional marriages?” It is interesting to examine these data by important demographic subgroups: gender, age, and political party affiliation. For example, women were slightly more likely than men to support same-gender marriage during the two years reported, 2012 and 2013. When we examine the impact of age, the younger respondents (under 50) supported the proposition by nearly two thirds, whereas of those 50 and older, only 4 in 10 expressed similar support. Finally, the sharpest differences were reported between those who identified their political affiliation as either 
Republican or Democrat: nearly 3 times as many Democrats (70\%) as Republicans (25\%) supported same-gender marriage.

Table 3. Attitudes toward Same-Gender Marriage by Gender, Age, and Political Party Affiliation, 2008-2013

\begin{tabular}{lccc}
\hline & $\begin{array}{c}\text { Should } \\
\%\end{array}$ & $\begin{array}{c}\text { Should not } \\
\%\end{array}$ & $\begin{array}{c}\text { Unsure } \\
\%\end{array}$ \\
\hline$\underline{2013}$ Men & 53 & 44 & 3 \\
Women & 49 & 48 & 3 \\
Under age 50 & 56 & 40 & 4 \\
50 and older & 61 & 36 & 3 \\
Democrats & 42 & 53 & 4 \\
Independents & 70 & 28 & 2 \\
Republicans & 55 & 41 & 4 \\
& 25 & 71 & 4 \\
2012 & & & 3 \\
Men & 54 & 42 & 5 \\
Women & 52 & 43 & 2 \\
Democrats & 56 & 28 & 2 \\
Independents & 70 & 37 & 4 \\
Republicans & 60 & 72 & 5 \\
2011 & 23 & 46 & 1 \\
2011 & & 47 & 2 \\
2009 & 53 & 54 & 2 \\
2008 & 51 & 55 & 1 \\
2008 & 44 & 53 & 3 \\
\hline
\end{tabular}

Question: "Do you think marriages between gay and lesbian couples should or should not be recognized by the law as valid, with the same rights as traditional marriages?”

Note ${ }^{\mathrm{a}}$ : Figures may not total $100 \%$ because of rounding.

Note $^{\mathrm{b}}$ : Data reported two or more times in one year indicate that the same question was asked multiple times.

Note $^{\mathrm{c}}: N=1,014$ adults nationwide with a margin of error of \pm 3 percentage points.

Noted : For each table, the authors have reported all data that were collected by the CNN/ORC Poll. However, it is important to note that the CNN/ORC Poll did not conduct the same survey every year, which explains the occasional gaps in data reported from year to year.

Source: Poll data compiled by the CNN/ORC Poll (2013). 


\section{Discussion}

What is most striking when we review the findings reported in Tables 1 and 2 are the substantial differences in support for same-gender marriage, ranging from a majority (53\%) expressing support for marriage equality to only 4 in 10 supporting same-gender marriage when Americans are offered three response alternatives: support for legalization of marriage, civil unions only, or no legal recognition of same-gender couples. An alternative interpretation emerges when we combine responses supporting civil unions and no legal recognition. More than 5 in 10 Americans support these two approaches, whereas only 4 in 10 support the right to legally marry.

For social workers committed to social action and legislative change, it is useful to be aware of the various demographic subgroups which support marriage equality, as reported by national polls. As such, this knowledge would provide a beginning point to focus on populations within states that have not approved same-gender marriage. Towards this end, when we examine the data in Table 3, two important demographic subgroups emerge: age and political party affiliation. When age is considered, those under 50 years of age are much more likely to support same-gender marriage than Americans 50 and over. Another national survey (CBS News Poll, 2013) reported a very strong relationship between age and support for same-gender marriage. For example, nearly 3 in 4 (73\%) of respondents aged 18-29 were in support of marriage equality. This level of support declines systematically through each older cohort without exception. For example, only 35\% of the oldest cohort (65+) supports same-gender marriage.

Political party affiliation yields the greatest response differences: Nearly three quarters of Democrats support same-gender marriage versus one quarter of Americans who consider themselves Republicans (see Table 3). It is useful to note that several national surveys have reported similar results (NBC News/Wall Street Journal, 2013; Pew Research Center, 2013, Princeton Survey Research Associates International, 2008; Quinnipiac University Poll, 2012).

Finally, regarding religious affiliation, the strongest support for same-gender marriage comes from the following demographic groups: Jewish Americans (81\%), the religiously unaffiliated Americans (76\%), Catholics (58\%), and mainline Protestants (55\%) (Jones, Cox, Navarro-Rivera, Dionne, \& Galston, 2013). Social workers may wish to look to these groups as their support base as they advocate for marriage equality.

The results from these national public opinion surveys may be useful for social workers who seek to advance social justice and marriage equality for the gay and lesbian population (National Association of Social Workers, 2012). There is a great deal of evidence that public opinion can directly influence public policy (Burstein, 2003; Kenworthy, 2009; Silver, 2013). For example, DOMA was approved under the Clinton Administration, when public opinion did not strongly support same-gender marriage. However, recently, the Supreme Court, some would argue, was influenced by public opinion, when it struck down DOMA and took no action on California's Prop 8 with a near majority supporting same-gender marriage. Some would also suggest that the 13 states that have approved same-gender marriage were influenced by national and statewide public opinion supporting same-gender marriage. 


\section{Study Limitations and Directions for Future Research}

\section{Study Limitations}

Numerous scholars have reported the limitations of survey research methodology (Creswell, 2013; Dillman, Smyth, \& Christian, 2009; Groves \& Couper, 2012; Groves et al., 2013). The findings can be impacted by numerous factors: the size, quality, and representativeness of the sample; survey type (face-to-face, online, mail, or telephone); question wording; question ordering; potential for social desirability response bias; number of response alternatives; and potential impact of various media announcements at the time of data collection (e.g., Supreme Court rulings, newspaper headlines, social media, etc.).

Limitations specifically related to data reported in Table 1 include a change in question wording from "homosexuals" to "same-sex couples" by the Gallup Organization. For example, in 2006, Gallup collected data twice that year, once using the question: "Do you think marriages between homosexuals should or should not be recognized by the law as valid, with the same rights as traditional marriages." In the same year, they changed the wording: "Do you think marriages between same-sex couples should or should not be recognized by the law as valid, with the same rights as traditional marriages?" We note that there was a negligible change in response rate from $39 \%$ agreeing that marriage should be valid to $42 \%$ when the second version of the question was asked. This difference is considered to be within the margin of error of \pm 3 percentage points, as reported by the Gallup Organization (see Note ${ }^{\mathrm{c}}$ in Table 1).

In examining the data in Table 2, we note the following limitations: The CBS News/New York Times Poll (2012) decided to frame their question differently than did Gallup in Table 1. Table 2 used the phrase "gay couples" as opposed to "same-sex couples" in Table 1. In addition to wording differences, Table 2 offered respondents three response alternatives: legal marriage, civil unions, and no legal recognition. It is interesting to note in Table 1 that when respondents are limited to one of two response categories-should be valid and should not be valid-53\% felt that same-gender marriage should be legally valid in 2012. However, when data were collected in 2012 by the CBS News/New York Times Poll, which provided three response alternatives, only $40 \%$ of Americans expressed support for legal marriage. It appears that the impact of question wording and the availability of several response alternatives yield substantially different results.

The data reported in Table 3 have the following limitations. It is interesting to note that the CNN/ORC Poll (2013) uses yet a third variation in question wording: "gay and lesbian couples"; however, the results for their 2012 survey are almost identical to Gallup's results (54\% and 53\%, respectively, supporting same-gender marriage). In addition, the age categories of "under 50 " and "50 and over" are extremely broad. However, other polling organizations report that for each cohort as age increases from youngest to oldest, there is a steady decline in support for same-gender marriage (Jones, 2013). Similarly, regarding political party affiliation, if respondents were given a fourth 
choice of no political affiliation, in addition to Democrat, Republican, or Independent, these results may yield a measurable difference.

\section{Future Research}

Future social work research might focus on the demographic subgroups in American society that do not support marriage equality. Findings from such research may shed light on how we can address the serious concerns of those Americans opposed to the legalization of same-gender marriage. To effectively conduct this research may require detailed, qualitative, face-to-face interviews, which generally provide much richer insights than can be gathered by using standard survey research methods. Collecting data from a sub-sample of Americans that do not support same-gender marriage is, of course, time consuming, costly, and may lack generalizability. Drawing from the results of these in-depth interviews may enable researchers to design meaningful questions that may have eluded earlier researchers who had used standard survey methodology.

Groups to be identified include the politically and religiously conservative as well as respondents over 50 years of age who typically report the lowest level of support for marriage equality. With this arsenal of detailed qualitative information, social workers could draw from these data as they pursue their various social policy advocacy efforts. In the past, social workers have only been armed with a thumbnail sketch of the demographic subgroups that are opposed to same-gender marriage, whereas the data gathered through this new research direction could provide a detailed breakdown of the reasons why certain demographic subgroups are opposed to the legalization of samegender marriage. Addressing such concerns may accelerate the progress towards full marriage equality for all Americans.

\section{Implications for Social Work Practice}

\section{Direct Practice}

The number of lesbian women and gay men who turn to therapy for help for any number of reasons is rapidly increasing. For example, $72 \%$ of American Association of Marriage and Family Therapy Clinical Members indicate that approximately one tenth of their practice is with lesbian and gay clientele (Green et al., 2009). Many practitioners are challenged to think outside of their comfortable and familiar heterosexist constructions of family life, thereby promoting a more gay- and lesbian-affirmative therapeutic stance (Green et al., 2009). Also, same-gender marriage partners often need counseling or therapy to assist with their constant struggle amidst layers of unsupportive laws, policies, and social attitudes. The impact of these struggles can negatively affect not only their finances and certain privileges and rights, but also, commonly, the mental and emotional well-being of the members of their family unit including partners and children.

Pre-marital education services, readily available to opposite-sex couples, are limited for same-gender couples. Premarital counseling could provide a wealth of support and guidance to lesbians, gays, and bisexuals to nurture their relationships in the midst of societal discrimination, legal prohibitions, and other forms of social injustice that are 
enacted against same-gender marriages. The development of programs to address these and related issues could be strengthened by linking same-gender and bisexual couples with successful couples who have experienced and resolved various challenges related to their sexual identities (Casquarelli \& Fallon, 2011).

Social workers also have an important role in addressing the "minority stress" that same-gender couples experience as a result of the lack of marriage equality. Minority stress is associated with increased risk for depression, anxiety, and other physical and psychological health outcomes. The denial of civil marriage rights is a specific example of minority stress that can negatively affect the psychosocial well-being of lesbians, gays, bisexuals, and the transgendered (Rostosky \& Riggle, 2011).

Some therapists have failed to explicitly attend to the social context of their gay and lesbian clients, which has sometimes led to ineffective practices (Green et al., 2009). With regard to same-gender partners involved in health care issues, in states where samegender marriage is not recognized, it could be important to guide them towards initiating a form of health care proxy to help approximate the kinds of rights that a heterosexual spouse would have in a medical emergency (Zupcofska, 2010).

\section{Macro Practice}

The lack of legalized marriage for same-gender couples directly affects their rights and psychological well-being. Furthermore, the Massachusetts Department of Public Health indicates that $93 \%$ of children with same-gender parents report feeling happier and better off as a result of the legal recognition of same-gender marriage (Buffie, 2011).

Further, social workers can take steps to become advocates for marriage equality by educating themselves about local and state laws that affect their clients (Rostosky \& Riggle, 2011). They can also facilitate marriage equality by conducting and disseminating research and by engaging in political advocacy efforts in conjunction with national organizations, such as the National Gay and Lesbian Task Force (NGLTF) and the Human Rights Campaign (HRC), which are nationally organized political voices for the U.S. LGBT community (Callahan, 2009). With regard to the need for premarital counseling for same-gender couples, social workers can play an important research role to increase their understanding (Casquarelli \& Fallon, 2011).

To help change the knowledge base in the courtroom, social workers can serve as informational consultants to politicians, attorneys, and judges. As an example of the critical role that social workers and other professionals can play, research psychologists testified on behalf of the plaintiffs during the 2010 federal district trial challenging the constitutionality of California's Proposition 8. One social scientist presented expert testimony and cited research on "minority stress"; another testified on the vast research literature demonstrating that child outcomes do not differ based on parent sexual orientation. The impact of such research is clear in the judge's decision in favor of marriage equality (Rostosky \& Riggle, 2011).

Researchers have reported in recent years that homophobic attitudes are decreasing; however, it is unclear whether attitudes are actually changing, or whether instead it is less 
socially desirable to admit having these attitudes (Green et al., 2010). Although intentional anti-gay behaviors are common, more common are unintentional anti-gay behaviors that some people engage in without conscious awareness. The impact of homophobia on gays and lesbians can be devastating, resulting in feelings of inadequacy, self-hatred, guilt, and a general lack of optimism (Blumer \& Murphy, 2011). This is an important observation since it can impact social work practice, particularly if social workers or their homophobic clients hold such attitudes and unintentionally harm LGBT individuals. Therefore, it is critical that social workers engage in serious self-reflection regarding their personal attitudes toward LGBT clients and how those attitudes may negatively impact the clients they are seeking to assist.

\section{Conclusion}

When we trace America's historical, cultural, and political roots surrounding samegender marriage equality, we observe a significant journey marked by the violence of the Stonewall riots in 1969 to the policy decision of the American Psychiatric Association to remove homosexuality as a mental health disorder from the DSM-IV manual in 1973. Nearly half a century later, today's national opinion surveys report a slight majority of Americans in support of same-gender marriage. It is interesting to note that American public opinion has often led the opinion of state and federal legislators on controversial issues, and this appears to be true today. Social workers who choose to advocate in this arena have a full agenda which involves a great deal of effort, but also requires a fundamental shift in how society views traditional marriage-a shift that Americans do not easily make. This is a challenging but not impossible undertaking. Today's social workers should be in the forefront in fighting for social justice and equality.

\section{References}

Agnone, J. (2007). Amplifying public opinion: The policy impact of the U.S. environmental movement. Social Forces, 85(4), 1593-1620.

Alessi, E. J. (2013). A framework for incorporating minority stress theory into treatment with sexual minority clients. Journal of Gay \& Lesbian Mental Health. Advance online publication.

Baker v. Nelson, 291 Minn. 310 (Minn. 1971), 409 U.S. 810 (1972).

Baker, M., \& Elizabeth, V. (2012). Negotiating 'marriage': Comparing same-sex and different-sex cohabiting couples. New Zealand Sociology, 27(2), 10-28.

Blekesaune, M., \& Quadagno, J. (2003). Public attitudes toward welfare state policies: A comparative analysis of 24 nations. European Sociological Review, 19(5), 415-427.

Blumer, M. L. C., \& Murphy, M. J. (2011). Alaskan gay males’ couple experiences of societal non-support: Coping through families of choice and therapeutic means. Contemporary Family Therapy, 33, 273-290. 
Bonvicini, K. A., \& Perlin, M. J. (2003). The same but different: Clinician-patient communication with gay and lesbian patients. Patient Education Counseling, 51(2), 115-122.

Buffie, W. C. (2011). Public health implications of same-sex marriage. American Journal of Public Health, 101(6), 986-990.

Burstein, P. (2003). The impact of public opinion on public policy: A review and an agenda. Political Research Quarterly, 56, 29-40.

Callahan, J. (2009). Same-sex marriage: Why it matters-at least for now. Hypatia, 24(1), 70-80.

Casquarelli, E. J., \& Fallon, K. M. (2011). Nurturing the relationships of all couples: Integrating lesbian, gay, and bisexual concerns into premarital education and counseling programs. Journal of Humanistic Counseling, 50, 149-160.

CBS News Poll. (2013). Same-sex marriage, gay rights. Retrieved from http://www.pollingreport.com/civil.htm

CBS News/New York Times Poll. (2012). Same-sex marriage, gay rights. Retrieved from http://www.pollingreport.com/civil.htm

CNN/ORC Poll. (2013). Same-sex marriage, gay rights. Retrieved from http://www.pollingreport.com/civil2.htm

Creswell, J. W. (2013). Research design: Qualitative, quantitative, and mixed methods approaches $\left(4^{\text {th }}\right.$ ed.). Thousand Oaks, CA: Sage.

Dillman, D. A., Smyth, J. D., \& Christian, L. M. (2009). Internet, mail, and mixed-mode surveys: The tailored design method. Hoboken, NJ: Wiley.

Duncan, M. L., \& Kemmelmeier, M. (2012). Attitudes toward same-sex marriage: An essentialist approach. Analyses of Social Issues and Public Policy, 12, 377-399.

Ellison, C. G., Acevedo, G. A., \& Ramos-Wada, A. I. (2011). Religion and attitudes toward same-sex marriage among U.S. Latinos. Social Science Quarterly, 92, 35-56.

Epstein, B. J. (2012). The nuclear gay family: Same-sex marriage in children's books. Gay \& Lesbian Issues and Psychology Review, 8(3), 142-152.

Franck, M. J. (2011). Religion, reason, and same-sex marriage. Institute of Religion and Public Life, 21, 47-52.

Gallup Organization. (2013). Marriage. Retrieved from http://www.gallup.com/poll/117328/Marriage.aspx

Geidner, C. (2011, May 4). Domestic disturbance. Metro Weekly [Online]. Retrieved from http://www.metroweekly.com/feature/?ak=6213

Goodstein, L. (2013, September 19). Pope says church is “obsessed” with gays, abortion, and birth control. New York Times, p. A1. 
Green, M. S., Murphy, M. J., \& Blumer, M. L. C. (2010). Marriage and family therapists' comfort working with lesbian and gay male clients: The influence of religious practices and support for lesbian and gay male human rights. Journal of Homosexuality, 57(10), 1258-1273.

Green, M. S., Murphy, M. J., Blumer, M., \& Palmanteer, D. (2009). Marriage and family therapists' comfort level working with gay and lesbian individuals, couples, and families. The American Journal of Family Therapy, 37, 159-168.

Groves, R. M., \& Couper, M. P. (2012). Nonresponse in household interview surveys. New York, NY: John Wiley \& Sons.

Groves, R. M., Fowler, F. J., Couper, M. P., Lepkowski, J. M., Singer, E., \& Tourangeau, R. (2013). Survey methodology $\left(2^{\text {nd }}\right.$ ed.). New York, NY: John Wiley \& Sons.

Gutis, P. (1989, November 5). Small steps toward acceptance renew debate on gay marriage. New York Times [Online]. Retrieved from http://www.nytimes.com/1989/11/05/weekinreview/ideas-trends-small-steps-towardacceptance-renew-debate-on-gay-marriage.html

Jones, J. M. (2013). Same-sex marriage support solidifies above 50\% in U.S. Retrieved from http://www.gallup.com/poll/162398/sex-marriage-support-solidifies-above.aspx

Jones, R. P., Cox, D., Navarro-Rivera, J, Dionne, E. J., \& Galston, W. A. (2013). Citizenship, values, and cultural concerns: What Americans want from immigration reform. Washington, DC: Public Religion Research Institute/Brookings.

Kenworthy, L. (2009). The effect of public opinion on social policy generosity. SocioEconomic Review, 7(4), 727-740.

Kipnes, P. (2013). For many Jewish youths, gay marriage is a new normal. Retrieved from http://www.reformjudaism.org/blog/2013/07/26/many-jewish-youth-gaymarriage-new-normal

Leitsinger, M. (2013). Rights within reach: For some gay couples, marriage is mere miles away-but that's still too far. Retrieved from http://usnews.nbcnews.com/_news/2013/07/19/19545738-rights-within-reach-forsome-gay-couples-marriage-is-mere-miles-away-but-thats-still-toofar?lite\&ocid=msnhp\&pos=1

Lofquist, D. (2011). Same-sex couple households. Washington, DC: U. S. Census Bureau. Retrieved from http://www.census.gov/prod/2011pubs/acsbr10-03.pdf

Marcus, L. L. (2013). OU disagrees with but respects Supreme Ct's rejection of Defense of Marriage Act. The Jewish Press [Online]. Retrieved from http://www.jewishpress.com/news/breaking-news/ou-disagrees-with-but-respectssupreme-cts-rejection-of-defense-of-marriage-act/2013/06/27/0/?print

National Association of Social Workers. (2012). Social work speaks: National Association of Social Workers policy statements, 2012-2014. Washington, DC: NASW Press. 
NBC News/Wall Street Journal. (2013). Same-sex marriage, gay rights. Retrieved from http://www.pollingreport.com/civil.htm

Nicolas, P. (2011). Common law same-sex marriage. Connecticut Law Review, 43(3), 931-947.

Penniman, T. V., Taylor, S. L., Bird, C. E., Beckman, R., Collins, R. L., \& Cunningham, W. (2007). The associations of gender, sexual identity, and competing needs with healthcare utilization among people with HIV/AIDS. Journal of the National Medical Association, 99, 419-427.

Perry v. Schwarzenegger, No. 10-16696 (9th Cir. Aug. 16, 2010).

Pew Research Center. (2013). Same-sex marriage, gay rights. Retrieved from http://www.pollingreport.com/civil.htm

Pew Research Religion \& Public Life Project. (2012, December). Religious Groups’ Official Positions on Same-Sex Marriage. Retrieved from http://www.pewforum.org/2012/12/07/religious-groups-official-positions-on-samesex-marriage/

Ponce, N. A., Cochran, S. D., Pizer, J. C., \& Mays, V. H. (2010). The effects of unequal access to health insurance for same-sex couples in California. Health Affairs (Project Hope), 29(8), 1539-1548.

Ponterotto, J. G., Casas, J. M., Suzuki, L. A., \& Alexander, C. M. (Eds.). (2010). Handbook of multicultural counseling ( $3^{\text {rd }}$ ed.). Thousand Oaks, CA: Sage.

Princeton Survey Research Associates International. (2008). Same-sex marriage, gay rights. Retrieved from http://www.pollingreport.com/civil.htm

Quinnipiac University Poll. (2012). Same-sex marriage, gay rights. Retrieved from http://www.pollingreport.com/civil.htm

Rostosky, S. S., \& Riggle, E. D. B. (2011). Marriage equality for same-gender couples: Counseling psychologists as social change agents. The Counseling Psychologist, 39(7), 956-972.

Sheppard, N. (1979, September 17). Panel bids Episcopalians bar homosexual priests. New York Times [Online]. Retrieved from http://query.nytimes.com/gst/abstract.html?res=F70917F7385413718DDDAE0994D 1405B898BF1D3

Sherkat, D. E., Powell-Williams, M., Maddox, G., \& Mattias de Vries, K. (2011). Religion, politics and support for same-sex marriage in the United States, 1988-2008. Social Science Research, 40, 167-180.

Shulman, J. L., Gotta, G., \& Green, R. J. (2012). Will marriage matter? Effects of marriage anticipated by same-sex couples. Journal of Family Issues, 33(2), 158-181.

Silver, N. (2013, March 26). How opinion on same-sex marriage is changing, and what it means. The New York Times [Online]. Retrieved from 
http://fivethirtyeight.blogs.nytimes.com/2013/03/26/how-opinion-on-same-sexmarriage-is-changing-and-what-it-means/? $\mathrm{r}=0$

Vermont lawyer proud of 1st state with civil unions. (2013). Retrieved from http://www.rutlandherald.com/article/20130626/THISJUSTIN/130629949/0/VIMEO $\underline{\text { VIDEO }}$

Walls, N. E. (2010). Religion and support for same-gender marriage: Implications from the literature. Journal of Gay and Lesbian Social Services, 22(1-2), 112-131.

Whitehead, A. L. (2010). Sacred rites and civil rights: Religion's effect on attitudes toward same-sex unions and the perceived cause of homosexuality. Social Science Quarterly, 91, 63-79.

Willetts, M. C. (2011). Registered domestic partnerships, same-sex marriage, and the pursuit of equality in California. Family Relations, 60, 135-149.

Williams Institute. (2011). United States Census snapshot. Los Angeles, CA: Author. Retrieved from http://williamsinstitute.law.ucla.edu/\#mapus

Woodford, M. R., Chonody, J., Scherrer, K., Silverschanz, P., \& Kulick, A. (2012). The "persuadable middle” on same-sex marriage: Formative research to build support among heterosexual college students. Sexuality Research and Social Policy, 9, 1-14.

Zernike, K. (2013, August 14). New Jersey court to hear same-sex marriage case. New York Times, p. A18.

Zupcofska, P. F. (2010). When couples are same sex, drafting considerations differ. Family Advocate, 32, 18-22.

\section{Author note:}

Address correspondence to: Dr. Darrel Montero, Arizona State University School of Social Work, MC 3920, 411 North Central Avenue, Ste. 800, Phoenix, AZ 85004-0689. Email: darrel.montero@asu.edu 